\title{
EKSPLORASI KEMAMPUAN REPRESENTASI VISUAL MAHASISWA CALON GURU DALAM MENYELESAIKAN MASALAH GEOMETRI BERDASARKAN PEMAHAMAN MATEMATIKA DAN GENDER
}

Try Nur Handayani ${ }^{1}$, Ma'rufi $^{2}$, Nurdin $^{3}$

Universitas Cokroaminoto Palopo 1,2,3

Email: trynurhdy11@gmail.com ${ }^{1}$, marufi@uncp.ac.id ${ }^{2}$, enambelasnurdin@gmail.com ${ }^{3}$

\begin{abstract}
Abstrak, 1 subjek laki-laki dan 1 subjek perempuan yang memiliki pemahaman matematika tinggi, sedang dan rendah. Metode yang digunakan dalam penelitian ini adalah metode deskriptif dengan pendekatan kualitatif dan data dalam penelitian ini diperoleh dari tes dan wawancara. Hasil penelitian ini menunjukkan bahwa; (1) kemampuan representasi matematika subjek laki-laki berkemampuan tinggi, sedang, dan rendah dalam menyelesaikan masalah bangun datar segitiga cenderung menggunakan representasi visual (2) kemampuan representasi matematika subjek perempuan berkemampuan tinggi, sedang, dan rendah dalam menyelesaikan masalah bangun datar segitiga cenderung menggunakan representasi visual.
\end{abstract}

Kata Kunci: Representasi Visual, Geometri, Pemahaman Matematika, Gender.

\begin{abstract}
This study aims to explore the representational abilities of prospective teacher students in solving geometry problems based on understanding mathematics and gender. This research was conducted in the Mathematics Education study program FKIP UNCP. The subjects of this study were students of the 2017 FKIP UNCP Mathematics Education study program which consisted of 1 male and 1 female subject each who had high, medium and low mathematics understanding. The method used in this research is descriptive method with a qualitative approach and the data in this study were obtained from tests and interviews. The results of this study indicate that; (1) the mathematical representation ability of male subjects with high, medium and low abilities in solving triangular flat shape problems tends to use visual representations, (2) the mathematical representation abilities of female subjects with high, medium, and low abilities in solving triangular flat shape problems tend to use visual representations.
\end{abstract}

Keywords: Visual Representation, Geometry, Mathematical Understanding, Gender.

\section{A. Pendahuluan}

Matematika merupakan salah satu bidang ilmu yang diajarkan dari jenjang pendidikan dasar sampai jenjang pendidikan tinggi. Oleh karena itu, matematika bertujuan untuk membekali siswa/mahasiswa dengan kemampuan berpikir logis, memahami konsep, analitis, sistematis, kritis, dan kreatif, serta kemampuan bekerjasama. Matematika merupakan ilmu yang erat hubungannya dengan angka, simbol, serta rumus-rumus. Matematika adalah suatu pola berpikir logis dalam mengorganisasikan ide dengan menggunakan bahasa istilah yang direpresentasikan dengan bahasa simbol (Suherman, 2001). Oleh karena itu, pada pembelajaran matematika perlu adanya suatu kemampuan yang mengembangkan peserta didik untuk dapat dengan mudah menyampaikan ide-ide dan gagasan dari permasalahan yang berupa simbolsimbol matematika, kemampuan inilah yang disebut dengan representasi. Representasi matematika adalah kemampuan yang menuntut siswa untuk dapat membuat suatu metode dari suatu masalah kedalam bentuk baru baik secara verbal, tulisan, grafik, tabel, ataupun gambar (Sabirin, 2014). 
Alasan pentingnya kemampuan representasi untuk peserta didik diungkapkan Jones (Cahdriyana, Sujadi, \& Riyadi, 2014) yaitu; (1) kelancaran dalam melakukan translasi di antara berbagai bentuk representasi berbeda, merupakan kemampuan mendasar yang perlu dimiliki siswa untuk membangun konsep dan berpikir matematis, (2) cara guru dalam meyajikan ideide matematika melalui berbagai representasi akan memberikan pengaruh yang sangat besar terhadap pemahaman siswa dalam mempelajari matematika, dan (3) siswa membutuhkan latihan dalam membangun representasinya sendiri sehingga memiliki kemampuan dan pemahaman konsep yang kuat dan fleksibel yang dapat digunakan dalam memecahkan masalah.

Representasi akan membantu siswa/mahasiswa untuk mengungkapkan ide-ide dan gagasan dalam menyelesaikan masalah. Ide-ide matematika dapat direpresentasikan ke dalam bentuk gambar, tabel, grafik, angka, huruf, simbol dan lain sebagainya. Goldin (2002) mengungkapkan bahwa representasi adalah elemen yang sangat penting untuk teori belajar mengajar matematika. Oleh karena itu

kemampuan representasi matematika sangat penting dan dibutuhkan oleh siswa, karena melalui representasi matematika siswa dapat menggambarkan, menerjemah, mengungkapkan, melambangkan atau memodelkan suatu konsep dalam matematika. Umumnya representasi dibedakan menjadikan representasi visual, verbal, dan aljabar.

Salah satu representsi matematika yang dilakukan dalam menyelesaikan suatu masalah adalah menggunakan representasi visual menurut Faradiba, Susiswo, \& As'ari (2019). Menurut Özkan, Arikan, \& Özkan (2018) mengatakan bahwa model visual memiliki kemampuan untuk membantu siswa dalam memahami masalah. Ainsworth \& VanLabeke (Faradiba dkk, 2019) mengatakan model visual seperti diagram dan gambar, merupakan alat yang kuat dalam pembelajaran matematika dan pemecahan masalah. Kemudian, (Ahmad, Tarmizi, \& Nawawi, 2010) mengatakan bahwa model visual dalam masalah matematika dapat memudahkan anak dalam membuat rencana penyelesaian. Dengan demikian, menggunakan model visual menjadi cara yang efektif untuk mendukung pemahaman masalah dan pemecahannya (Van Garderen \& Montague, 2003). Cramer (Faradiba dkk, 2019) juga mengungkapkan bahwa mengubah masalah matematika ke dalam bentuk visual akan membuat gagasan lebih bermakna bagi siswa. Selanjutnya, representasi visual sangat dibutuhkan dalam memecahkan masalah matematika (Stylianou, 2011). Oleh karena itu, model visual sudah seharusnya dikuasai oleh siswa karena sangat diperlukan dalam pembelajaran matematika. Selanjutnya, model visual juga merupakan bentuk representasi yang penting dan diperlukan untuk mendukung pemahaman dan pemecahan masalah matematika.

Pada representasi, objek yang mewakili gagasan atau ide-ide dari seseorang disebut representasi. Objek dalam matematika bersifat abstrak sehingga untuk mempelajari dan memahami ide-ide abstrak itu diperlukan pemahaman yang lebih lanjut. Salah satu cabang ilmu matematika yang berkaitan dengan ide-ide abstrak tersebut adalah Geometri. Risnawati (2012) menyatakan bahwa dari sudut pandang psikologi, geometri merupakan penyajian abstraksi dari pengalaman visual dan spasial, misalnya bidang, pola, pengukuran dan pemetaan, sedangkan dari sudut pandang matematika, geometri menyediakan pendekatan-pendekatan untuk pemecahan masalah berupa: gambar-gambar, diagram, system koordinat, vector

dan transformasi. Oleh karena itu kebiasaan pemecahan masalah melalui soal-soal geometri sangatlah penting dalam meningkatkan kemampuan representasi matematika siswa, karena geometri memiliki keabstrakan objek, sehingga menuntut siswa untuk mampu membayangkan hal-hal yang tidak jelas bentuk fisiknya (tidak nyata).

Geometri merupakan cabang matematika yang berhubungan tentang titik, garis, bidang dan ruang. Geometri adalah ilmu dalam cabang matematika yang mengenai tentang ukuran, letak dan bentuk suatu benda/objek (Marufi, Pasandaran, \& Yogi, 2018). Materi geometri dapat diaplikasikan secara luas dalam kehidupan sehari-hari, mulai dari bidang pertanian, 
pembangunan, sampai bidang teknologi dan informasi. Kenyataan di lapangan, materi yang menjadi momok bagi mahasiswa calon guru matematika adalah materi geometri. Hal ini disebabkan karena mahasiswa masih sulit menyampaikan gagasan atau ide pemahamanpemahaman tentang konsep yang dimilikinya ke dalam bentuk kata-kata (tulisan) atau mengubah dari abstrak ke konkret sehingga dapat dengan mudah untuk memahaminya.

Penggunaan representasi yang benar oleh siswa/mahasiswa akan membantu siswa/mahasiswa dalam menyederhanakan masalah geometri dan menyelesaikan masalah tersebut secara lebih efektif. Wahyuni (Mulyati, 2016) menyatakan bahwa suatu masalah yang rumit akan menjadi lebih sederhana jika menggunakan representasi yang sesuai dengan permasalahan yang diberikan, sebaliknya penggunaan representasi yang keliru dalam menyelesaikan masalah akan membuat masalah tersebut menjadi lebih sukar untuk diselesaikan. Sehingga penggunaan representasi sangat memungkinkan bagi siswa/mahasiswa untuk mencoba berbagai strategi-strateginya dalam menyelesaikan masalah geometri. Contohnya, ketika siswa/mahasiswa disuruh menyebutkan pasangan segitiga yang kongruen atau sebangun dari bangun datar gabungan yang diberikan, maka siswa memulai dengan proses mengabstraksi atau mengvisualkan gambar tersebut. Proses mengabstraksi atau mengvisualkan inilah yang merupakan kemampuan representasi. Namun, kenyataanya siswa/mahasiswa keliru saat menyelesaikan masalah tersebut karena pada saat proses mengabstraksi atau mengvisualkan gambar, maka siswa/mahasiswa akan memanfaatkan pemahaman-pemahaman yang sudah

dimiliki sebelumnya. Sehingga, ketika pemahaman siswa kurang mengenai hal tersebut, maka siswa akan mudah keliru dalam menyelesaikannya. Setiap siswa/mahasiswa memiliki pemahaman-pemahaman berbeda dalam mempresentasikan suatu masalah geometri. Hal ini dikarenakan setiap siswa/mahasiswa memiliki kemampuan pemahaman yang tidak sama. Salah satu faktor yang mempengaruhi perkembangan kemampuan representasi dalam menyelesaikan geometri adalah pemahaman matematika.

Pemahaman matematika adalah kemampuan awal yang harus dimiliki siswa untuk memahami kemampuan yang lainnya. Pemahaman matematika sebagai salah satu tujuan yang diharapkan bisa dikuasai dan dicapai dengan baik oleh siswa. Delvin (Ruswana, 2019) menyatakan bahwa pemahaman merupakan unsur penting dalam setiap pembelajaran di semua jenjang pendidikan, baik jenjang pendidikan persekolahan maupun perguruan tinggi. Pemahaman berkaitan dengan penguasaan atau mengerti tentang sesuatu. Kemampuan pemahaman merupakan kemampuan paling mendasar yang harus dimiliki mahasiswa karena kemampuan ini bisa menunjang mahasiswa untuk mencapai kemampuan berpikir matematika lainnya. Menurut Ilyas \& Basir (2016) pemahaman konsep matematika sangat penting, karena dengan penguasaan konsep akan memudahkan siswa dalam mempelajari matematika. Hal ini berarti mahasiswa memerlukan pemahaman matematika yang baik untuk menyelesaikan masalah matematika dan dari pemahaman tersebut mahasiswa dapat merepresentasikan masalah ke dalam kata-kata, gambar, grafik, tabel, dan persamaan-persamaan.

Selain pemahaman matematika, perbedaan gender juga mempengaruhi kemampuan representasi mahasiswa dalam menyelesaikan masalah geometri. Utaminingsih (2017) mengutarakan gender adalah perbedaan yang tampak antara laki-laki dan perempuan apabila dikaji berdasarakan nilai dan perilakunya. Hasil penelitian dari Amaliyah (2017) mengungkapkan bahwa subjek berjenis kelamin laki-laki (SL) cenderung lebih representatif dalam memecahkan masalah-masalah matematika yang diajukan, dimana subjek menyajikan aspek-aspek representasi matematika berupa representasi visual, ekspresi matematika dan representasi tulisan maupun verbal secara baik pada pada semua masalah yang diajukan. Sedangkan, subjek berjenis kelamin perempuan (SP) cenderung kurang

representatif dalam memecahkan masalah-masalah matematika yang diajukan, dimana subjek menyajikan aspek-aspek representasi matematika berupa representasi visual, ekspresi 
matematika dan representasi tertulis lainnya yang kurang jelas, tapi mampu representasi tersebut secara verbal. Hal ini menunjukkan bahwa terdapat perbedaan antara laki-laki dan perempuan dalam merepresentasikan sesuatu.

\section{B. Metode Penelitian}

1. Jenis Penelitian

Penelitian ini adalah penelitian deskriftif dengan menggunakan pendekatan kualitatif atau dinamakan penelitian deskriftif kualitatif. Penelitian ini menggunakan pendekatan kualitatif dengan harapan agar dapat mengungkapkan secara cermat kemampuan representasi visual matematika yang dimiliki mahasiswa dalam menyelesaikan masalah geometri berdasarkan pemahaman matematika dan gender.

\section{Subjek Penelitian}

Subjek dalam penelitian ini terdiri dari 6 mahasiswa yaitu 1 mahasiswa laki-laki yang memiliki pemahaman matematika tinggi, 1 mahasiswa perempuan yang memiliki pemahaman matematika tinggi, 1 mahasiswa laki-laki yang memiliki pemahaman matematika sedang, 1 mahasiswa perempuan yang memiliki pemahaman matematika sedang, 1 mahasiswa laki-laki yang memiliki pemahaman matematika rendah, dan 1 mahasiswa perempuan yang memiliki pemahaman matematika rendah. Langkah-langkah penentuan subjek sebagai berikut: (1) Mendata mahasiswa mahasiswa Program Studi Pendidikan Matematika Fakultas Keguruan dan Ilmu Pendidikan Universitas Cokroaminoto Palopo angkatan 2017 sebagai calon subjek penelitian, (2) Memberikan tes pemahaman matematika yang berhubungan dengan materi geometri yang telah mereka pelajari kepada setiap calon subjek penelitian, (3) Menganalisis hasil tes pemahaman matematika calon subjek penelitian. Hasil tes pemahaman matematika dianalisa dengan menggunakan pemberian skor (rubrik penilaian) terhadap setiap butir soal yang diteskan. (4) Mengelompokkan setiap calon subjek penelitian berdasarkan kriteria pemahaman matematika dan gender. Hasil pengelompokan ini dapat dilihat pada tabel 1 berikut.

Tabel 1. Hasil pengelompokan tes pemahaman matematika dan gender

\begin{tabular}{lccccc}
\hline & Kategori & \multicolumn{2}{c}{ Banyak Mahasiswa } & \multicolumn{2}{c}{ Persentase (\%) } \\
& Pemahaman Matematika & Laki-laki & Perempuan & Laki-laki & Perempuan \\
\hline Tinggi & 3 & 7 & 33,33 & 15,22 \\
Sedang & 5 & 29 & 55,56 & 63,04 \\
Rendah & 1 & 10 & 11,11 & 21,74 \\
\hline Jumlah & 9 & 46 & 100 & 100 \\
\hline
\end{tabular}

\section{Teknik Pengumpulan Data}

Pengumpulan data dalam penelitian ini akan dilakukan dengan dua teknik yatu tes tertulis dan wawancara. Proses pengumpulan data tes tertulis diperoleh dari hasil tes pemahaman matematika dan tes representasi visual. Pengumpulan data diawali dengan pemberian tes pemahaman matematika. Kemudian data dari tes pemahaman matematika yang diperolah digunakan untuk menentukan subjek penelitian yaitu 6 mahasiswa yang terdiri dari 3 mahasiswa laki-laki dan 3 mahasiswa perempuan. Proses berikutnya, subjek diberikan soal tes representasi visual dan dilakukan wawancara terhadap subjek berdasarkan hasil pekerjaannya.

Setelah data terkumpul maka dilakukan pemeriksaan keabsahan data. Keabsahan data merupakan konsep penting dalam penelitian kualitatif. Pemeriksaan terhadap keabsahan data bertujuan untuk mengurangi bias yang terjadi pada saat pengumpulan data. Dengan pemeriksaan keabsahan data peneliti akan lebih yakin bahwa data yang diperoleh benar-benar valid dan reliabel. Agar data yang diperoleh bisa memperoleh keabsahan data, maka dalam penelitian ini teknik pemeriksaan keabsahan data dilakukan dengan menggunakan teknik triangulasi. 
Triangulasi adalah usaha untuk mengecek/memeriksa kebenaran data atau informasi yang diperoleh peneliti dari berbagai sudut pandang yang berbeda dengan cara mengurangi sebanyak mungkin bias yang terjadi pada saat pengumpulan dan analisis data. Peneliti dalam penelitian ini triangulasi yang digunakan adalah triangulasi teknik. Triangulasi teknik dilakukan dengan cara mengecek data pada sumber yang sama dengan teknik yang berbeda yaitu tes dan wawancara.

\section{Teknik Analisis Data}

Proses analisis data dilakukan mengikuti langkah-langkah berikut: (1) Menelaah seluruh data yang tersedia dari berbagai sumber, yaitu dari wawancara, pengamatan yang sudah dituliskan dalam catatan lapangan dan hasil tes kemampuan representasi visual matematika, (2) Reduksi data adalah kegiatan yang mengacu pada proses menyeleksi, memfokuskan, mengabstraksikan, dan mentransformasikan data mentah. Dalam penelitian ini dilakukan dengan membuat rangkuman yang terdiri dari inti, proses, pernyataan-pernyataan yang sesuai dengan tujuan penelitian. Kata-kata subjek yang tidak sesuai dengan tujuan penelitian dihilangkan. Validasi data dilakukan pada saat pengumpulan data berlangsung, yaitu dengan cara verifikasi. Verifikasi data yang digunakan dalam penelitian ini adalah triangulasi teknik. Triangulasi teknik digunakan untuk mevalidasi data dari sumber yang sama dengan metode yang berbeda, yaitu tes dan wawancara, (3) Penyajian data yang meliputi pengklasifikasian dan identifikasi data, yaitu menuliskan kumpulan data yang terorganisir dan terkategori sehingga memungkinkan untuk menarik kesimpulan dari data tersebut. Dalam penelitian ini, data hasil wawancara tentang yang direduksi dikategorikan berdasarkan indikator yang diamati. Hal ini dimaksudkan agar informasi yang diperoleh dapat disimpulkan dengan mudah. (4) Membuat coding atau kode yang bertujuan untuk memudahkan pemaparan data. (5) Memaparkan data hasil wawancara dari hasil tes kemampuan representasi visual matematika mahasiswa. (6) Menafsirkan data/menarik kesimpulan penelitian dari data yang sudah dikumpulkan dan memverifikasi kesimpulan tersebut. Penarikan kesimpulan dilakukan berdasarkan analisis terhadap data yang telah dikumpulkan baik melalui tes, maupun wawancara terhadap subjek. Hal ini dilakukan dengan cara membandingkan hasil pekerjaan subjek dengan hasil wawancara sehingga dapat ditarik kesimpulan yang benar tentang kemampuan representasi visual matematika yang dimiliki oleh mahasiswa dalam menyelesaikan masalah geometri.

\section{Hasil dan Pembahasan}

Selama proses menyelesaikan masalah bangun datar segitiga yang diberikan terdapat beberapa perbedaan representasi visual yang dilakukan oleh subjek pemahaman matematika tinggi, sedang, dan rendah antara laki-laki dan perempuan. Perbedaan tersebut terlihat pada tabel 2 berikut: 
Tabel 2. Ringkasan kemampuan representasi visual mahasiswa laki-laki dan perempuan dalam memecahkan masalah bangundatar segitiga berdasarkan pemahaman matematika tinggi

\begin{tabular}{|c|c|}
\hline SLT & SPT \\
\hline $\begin{array}{l}\text { Pada soal nomor 2a subjek menuliskan dan } \\
\text { menjelaskan langkah membuat ilustrasi gambar dari } \\
\text { informasi yang diberikan dimulai dengan membuat } \\
\text { sebuah jajargenjang dengan memberikan nama RSTV } \\
\text { dan menuliskan panjang } R V \text { dan } T V \text {, kemudian } \\
\text { menggambarkan titik W pada } R S \text { dan membuat garis } \\
\text { dari titik V ke W yang tegak lurus dengan } R S \text { dimana } \\
\text { panjang } V W=8 \mathrm{~cm} \text { dan titik X pada } T S \text { dan membuat } \\
\text { garis dari titik V ke X yang tegak lurus dengan } T S \text {. } \\
\text { Terakhir, subjek membuat titik Y berada di tengah- } \\
\text { tengah garis } V S \text { dan menarik garis dari titik W ke titik } \\
\text { Y. }\end{array}$ & $\begin{array}{l}\text { Pada soal nomor 2a subjek menulsikan dan } \\
\text { menjelaskan langkah membuat ilustrasi gambar dari } \\
\text { informasi yang diberikan, meskipun garis tinggi } V X \\
\text { yang dibuat tidak memuat konsep garis tinggi dan } \\
\text { garis } W Y \text { tidak sesuai dengan informasi yang diminta } \\
\text { pada soal. Subjek memulai dengan membuat sebuah } \\
\text { jajargenjang RSTV dan menuliskan panjang } R V \text { dan } \\
T V \text {, kemudian menggambarkan titik W pada } R S \text { dan } \\
\text { membuat garis tinggi dari titik V ke W dengan } \\
\text { panjang } V W=8 \mathrm{~cm} \text { dan titik X pada } T S \text { yang } \\
\text { membagi dua garis } T S \text { dan membuat garis tinggi dari } \\
\text { titik V ke X. Terakhir, subjek membuat titik Y berada } \\
\text { pada garis } V T \text {, kemudian membuat garis dari titik W } \\
\text { ke titik Y yang membagi dua diagonal } V S \text {. }\end{array}$ \\
\hline $\begin{array}{l}\text { Pada soal nomor la subjek menuliskan tiga pasangan } \\
\text { segitiga yang kongruen yaitu segitiga DFE kongruen } \\
\text { dengan segitiga DCB, segitiga AFE kongruen dengan } \\
\text { segitiga DFE dan segitiga AFE kongruen dengan } \\
\text { segitiga DCB, serta menjelaskan dengan memberikan } \\
\text { bukti kekongruenan pasangan segitiga yang } \\
\text { ditemukan yaitu berdasarkan postulat sisi-sudut-sisi. }\end{array}$ & $\begin{array}{l}\text { Pada soal nomor la subjek menuliskan satu pasangan } \\
\text { segitiga yang kongruen dan menjelaskan dengan } \\
\text { memberikan bukti kekongruenan pasangan segitiga } \\
\text { yang ditemukan yaitu karena sisi yang sama panjang } \\
\text { dan sudut yang sama besar. }\end{array}$ \\
\hline $\begin{array}{l}\text { Pada soal nomor } 2 \text { b subjek menuliskan dua pasangan } \\
\text { segitiga-segitiga yang sebangun yaitu segitiga VWR } \\
\text { sebangun dengan segitiga VXT dan segitiga WYV } \\
\text { dengan segitiga WYS. }\end{array}$ & $\begin{array}{l}\text { Pada soal nomor } 2 \text { b subjek menuliskan menuliskan } \\
\text { satu pasangan segitiga yang sebangun dan } \\
\text { menjelaskan dengan memberikan bukti } \\
\text { kesebangunan segitiga tersebut yaitu bentuknya sama } \\
\text { dan sudutnya sama besar. }\end{array}$ \\
\hline
\end{tabular}

Berdasarkan tabel 2, terlihat bahwa subjek pemahaman matematika tinggi laki-laki (SLT) dan subjek pemahaman matematika tinggi perempuan (SPT) dalam menyelesaikan masalah bangun datar segitiga cenderung terhadap kemampuan representasi visual. Pada soal membuat ilustrasi gambar dari wacana yang diberikan, subjek SLT menggambar bangun berdasarkan informasi soal dengan menggunakan konsep jajargenjang dan garis tinggi. Saat dilakukan wawancara subjek SLT juga menjelaskan secara terstruktur bagaimana subjek menggambarkan bangun tersebut. Begitupun juga dengan subjek SPT, subjek telah menggambar bangun dengan menggunakan konsep jajargenjang, garis tinggi, dan garis membagi dua diagonal. Namun subjek keliru saat menggambarkan garis tinggi $V \bar{X}$, dimana yang dibuat tidak memuat konsep garis tinggi, karena subjek menarik garis tinggi tidak tegak lurus dengan sisi $S T \bar{T}$ dan membagi

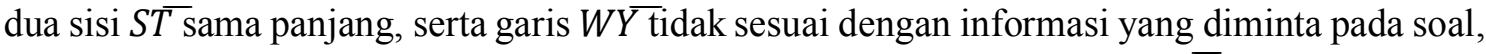
karena subjek tidak memahami maksud dari membagi dua diagonal $V \bar{S}$ sehingga subjek menggambarkan dengan membagi dua diagonal $V \bar{S}$ hingga menembuas sampai garis $V \bar{T}$. Saat dilakukan wawancara subjek juga keliru dalam memahami konsep garis tinggi, dimana subjek mengatakan bahwa garis tinggi adalah garis yang tegak lurus dengan sisi yang di depannya dan garis tingginya kadang membagi dua dan kadang juga tidak membagi dua.

Pada soal menemukan pasangan segitiga kongruen dan segitiga sebangun, subjek SLT menemukan tiga pasangan segitiga kongruen dan dua pasangan segitiga sebangun. Subjek menuliskan bukti kekongruenan dari tiga pasangan segitiga yang ditemukan berdasarkan postulat sisi-sudut-sisi. Saat dilakukan wawancara subjek juga menjelaskan ada tiga pasangan segitiga kongruen yang ditemukan dari gambar dengan membuktikan kekongruenannya berdasarkan postulat sisi-sudut-sisi. Pada hasil tes tertulis, subjek menemukan ada dua pasangan segitiga sebangun, namun subjek tidak menuliskan bukti kesebangunanya. saat 
dilakukan wawancara subjek dapat menjelaskan bukti kesebangunan dua pasangan segitiga sebangun yang ditemukan. Namun, satu dari dua pasangan segitiga sebangun yang dijelaskan subjek tidak memuat konsep kesebangunan, karena konsep kesebangunan yang dipahami subjek hanya sebatas bentuknya serupa, walaupun panjang sisi dan sudut yang berseseuaian tidak sama. Begitpun juga dengan subjek SPT, subjek menemukan masing-masing satu pasangan segitiga kongruen dan sebangun. Subjek menuliskan bukti kekongruenan segitiga yang ditemukan berdasarkan sisi-sisi yang sama panjang dan sudut sama besar. Saat dilakukan wawancara, subjek menjelaskan hal yang sama dengan menyebutkan sisi yang sama panjang adalah $A F=C D$ dan sudut sama besar adalah $m \angle E F A=m \angle B C D=90^{\circ}$. Pada hasil tes tertulis, SPT menemukan satu pasangan segitiga sebangun dan membuktikannya berdasarkan bentuknya sama dan besar sudutnya sama. Saat dilakukan wawancara, subjek menjelaskan hal yang sama dengan hasil tes tertulisnya. Namun, segitiga sebangun yang disebutkan SPT tidak memuat konsep kesebangunan, karena konsep kesebangunan yang dipahami subjek yaitu bentuknya sama, ukurannya bisa sama panjang dan juga boleh ada yang besar dan kecil, serta sudutnya juga sama besar. Hal tersebut mengungkapkan bahwa subjek laki-laki lebih unggul dalam dalam memvisualkan suatu gambar daripada subjek perempuan. Hal ini sesuai dengan yang dikemukakan Eisenberg dkk (Santrock, 2004) bahwa umumnya laki-laki memiliki kemampuan visual-spasial yang lebih baik dibandingkan dengan perempuan.

\section{Tabel 3. Ringkasan kemampuan representasi visual mahasiswa laki-laki dan perempuan dalam memecahkan masalah bangundatar segitiga berdasarkan pemahaman matematika sedang}

\begin{tabular}{|c|c|}
\hline SLS & SPS \\
\hline $\begin{array}{l}\text { Pada soal nomor 2a subjek menuliskan dan } \\
\text { menjelaskan langkah membuat ilustrasi gambar } \\
\text { dari informasi yang diberikan, meskipun subjek } \\
\text { keliru pada saat menggambarkan garis tinggi } \\
V W \text { dan garis tinggi } V X \text {, dimana subjek } \\
\text { menggambarkan titik W pada perpanjangan } \\
\text { garis } R S \text { dan titik X pada perpanjangan garis } S T \text {. } \\
\text { Subjek memulai dengan membuat sebuah } \\
\text { jajargenjang RSTV dan menuliskan panjang } R V \\
\text { dan } T V \text {, kemudian menggambarkan titik W pada } \\
\text { perpanjangan } R S \text { untuk membuat garis tinggi } \\
\text { dan titik X pada perpanjangan } T S \text { untuk } \\
\text { membuat garis tinggi. Terakhir, subjek membuat } \\
\text { garis } W Y \text { dengan terlebih dahulu membuat } \\
\text { diagonal } V S \text { dan menempatkan titik Y di tengah } \\
\text { diagonal } V S \text {, serta menarik garis dari W ke Y. }\end{array}$ & $\begin{array}{l}\text { Pada soal nomor 2a subjek menulsikan dan } \\
\text { menjelaskan langkah membuat ilustrasi gambar } \\
\text { dari informasi yang diberikan, meskipun } \\
\text { terdapat kekeliruan pada saat mengambarkan } \\
\text { sebuah garis tinggi } V W \text {. Subjek memulai dengan } \\
\text { menggambarkan jajargenjang RSTV dan } \\
\text { menuliskan panjang } R V \text { dan } T V \text {. Kemudian, } \\
\text { menggambarkan titik W di tengah-tengah garis } \\
R S \text { dan titik X pada } T S \text {, dengan } V W \text { dan } V X \\
\text { adalah garis tinggi. Selanjutnya subjek } \\
\text { menggambarkan garis } W Y \text {, dimana titik Y } \\
\text { membagi dua diagonal } V S \text {. Namun, garis } V W \\
\text { yang digambarkan subjek tidak memuat unsur } \\
\text { garis tinggi, ini terlihat dari ungkapan subjek } \\
\text { sudut W pada segitiga VWR dan segitiga VWS } \\
\text { tidak membentuk sudut siku-siku. }\end{array}$ \\
\hline $\begin{array}{l}\text { Pada soal nomor la subjek menuliskan satu } \\
\text { pasangan segitiga yang kongruen dan } \\
\text { menjelaskan dengan memberikan bukti } \\
\text { kekongruenan pasangan segitiga yang } \\
\text { ditemukan dengan postulat sisi-sudut-sisi. }\end{array}$ & $\begin{array}{l}\text { Pada soal nomor 1a subjek menuliskan dua } \\
\text { pasangan segitiga-segitiga yang kongruen dan } \\
\text { menjelaskan dengan memberikan bukti } \\
\text { kekongruenan pasangan segitiga yang } \\
\text { ditemukan dengan postulat sisi-sudut-sisi. }\end{array}$ \\
\hline $\begin{array}{l}\text { Pada soal nomor } 2 \mathrm{~b} \text { subjek menuliskan satu } \\
\text { pasangan segitiga yang sebangun dan } \\
\text { menjelaskan dengan memberikan bukti } \\
\text { kesebangunan segitiga tersebut berdasarkan } \\
\text { perbandingan sisi bersesuaiannya senilai. }\end{array}$ & $\begin{array}{l}\text { Pada soal nomor } 2 \text { b subjek menuliskan } \\
\text { menuliskan satu pasangan segitiga yang } \\
\text { sebangun dan menjelaskan dengan memberikan } \\
\text { bukti kesebangunan pasangan segitiga yang } \\
\text { ditemukan }\end{array}$ \\
\hline
\end{tabular}

Berdasarkan tabel 3, terlihat bahwa subjek pemahaman matematika sedang laki-laki (SLS) dan subjek pemahaman matematika sedang perempuan (SPS) dalam menyelesaikan 
masalah bangun datar segitiga cenderung terhadap kemampuan representasi visual. Pada soal membuat ilustrasi gambar dari wacana yang diberikan, subjek SLS menggambar bangun berdasarkan informasi soal dengan menggunakan konsep jajargenjang, garis tinggi, dan garis bagi. Namun, subjek SLS keliru dalam menggambarkan titik W dan titik X untuk membentuk

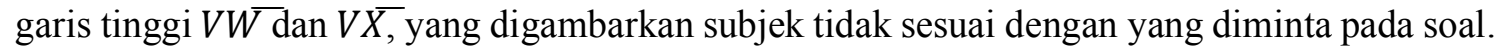
Saat dilakukan wawancara subjek SLS juga menjelaskan langkah-langkah menggambaran bangun tersebut dan kekeliruan yang dialami subjek pada saat menggambar terungkap pada wawancara bahwa subjek kesulitan dan bingung untuk menentukan garis $V W$. Karena, garis

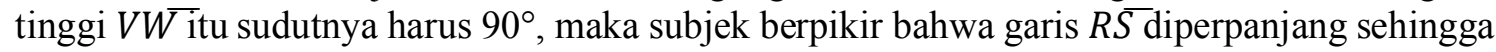

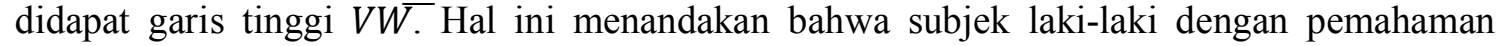
matematika sedang lemah dalam pemahaman konseptualnya. Begitupun juga dengan subjek SPS, subjek telah menggambar bangun ruang dengan menggunakan konsep jajargenjang, garis tinggi, dan membagi dua diagonal, namun garis tinggi $V \bar{X}$ yang dibuat subjek tidak memuat konsep garis tinggi, serta garis $W \bar{Y}$ tidak sesuai dengan informasi yang diminta pada soal. Saat dilakukan wawancara subjek SPS juga menjelaskan langkah-langkah menggambaran bangun tersebut dan kekeliruan yang dialami adalah subjek tidak memahami maksud dari membagi dua diagonal $V \bar{S}$ sehingga subjek menggambarkan dengan membagi dua diagonal $V \bar{S}$ hingga menembus sampai garis $V \bar{T}$ dan konsep garis tinggi yang dipahami subjek adalah garis tinggi tidak selalu memuat sudut siku-siku. Hal ini juga menandakan bahwa subjek perempuan dengan pemahaman matematika sedang juga lemah dalam pemahaman konseptualnya. Hal ini sejalan dengan hasil penelitian Kusuma \& Masduki (2016) bahwa siswa yang termasuk dalam kategori mempunyai kemampuan sedang, cenderung ada memiliki pemahaman prosedural yang cukup baik namun lemah pada pemahaman konseptual, serta ada yang memiliki pemahaman konseptual dan prosedural cukup baik.

Pada soal menemukan pasangan segitiga kongruen dan segitiga sebangun, subjek SLS menemukan satu pasangan segitiga kongruen dan satu pasangan segitiga sebangun. Subjek menuliskan bukti kekongruenan dari pasangan segitiga yang ditemukan berdasarkan postulat sisi-sudut-sisi. Namun, segitiga kongruen yang disebutkan oleh subjek tidak memuat konsep kekonruenan itu sendiri, karena titik sudut dari segitiga yang dituliskan subjek tidak bersesuaian. Saat dilakukan wawancara subjek juga menjelaskan pasangan segitiga kongruen yang ditemukan dari gambar dengan membuktikan kekongruenannya berdasarkan postulat sisisudut-sisi, dan masih tetap keliru karena titik sudut dari segitiga yang dijelaskan subjek tidak bersesuaian. Pada hasil tes tertulis, subjek menemukan ada satu pasangan segitiga sebangun berdasarkan perbandingan sisi bersesuaiannya senilai. Saat dilakukan wawancara subjek dapat menjelaskan bukti kesebangunan pasangan segitiga sebangun yang ditemukan. Begitpun juga dengan subjek SPS, subjek

menemukan dua pasangan segitiga kongruen berdasarkan postulat sisi-sudut-sisi dan satu pasangan segitiga sebangun berdasarkan perbandingan sisinya. Saat wawancara subjek juga menjelaskan hal yang sama, namun segitiga sebangun yang disebutkan SPS tidak memuat konsep kesebangunan, karena konsep kesebangunan yang dipahami subjek yaitu perbandingan sisi yang senilai dan memiliki sudut yang sama besar. Hal tersebut mengungkapkan bahwa terdapat kekeliruan baik subjek laki-laki maupun pada saat menyelesaikan soal, yang dikarenakan karena pemahaman konseptual siswa lemah, namun dari segi prosedural sudah baik. Adapun perbedaannya pada subjek laki-laki lebih baik dalam mengvisualkan suatu gambar daripada perempuan. Hal ini sesuai dengan yang dikemukakan oleh Maccoby dan Jacklyn (Imamuddin, 2018) bahwa laki-laki lebih unggul dalam kemampuan visual spatial (penglihatan keruangan) daripada perempuan. 
Tabel 4. Ringkasan kemampuan representasi visual mahasiswa laki-laki dan perempuan dalam memecahkan masalah bangundatar segitiga berdasarkan pemahaman matematika rendah

\begin{tabular}{|c|c|}
\hline $\begin{array}{l}\text { SLR } \\
\end{array}$ & SPR \\
\hline $\begin{array}{l}\text { Pada soal nomor 2a subjek menuliskan dan } \\
\text { menjelaskan langkah membuat ilustrasi gambar dari } \\
\text { informasi yang diberikan, meskipun subjek keliru } \\
\text { pada saat menggambarkan garis tinggi } V X \text {, dimana } \\
\text { subjek membuat titik X pada perpanjangan garis } R S \\
\text { dan menarik garis dari titik V ke titik X dengan } \\
\text { memotong garis } T S \text {. Subjek memulai dengan } \\
\text { membuat sebuah jajargenjang RSTV. Kemudian } \\
\text { membuat membuat garis tinggi dari titik V ke titik W } \\
\text { dan membuat garis dari titik V ke titik X yang } \\
\text { melewati garis } T S \text {, serta membuat garis dari titik W } \\
\text { ke titik Y dengan titik Y berada di tengah garis } V S \text {. }\end{array}$ & $\begin{array}{l}\text { Pada soal nomor 2a subjek menuliskan dan } \\
\text { menjelaskan langkah membuat ilustrasi gambar dari } \\
\text { informasi yang diberikan, meskipun subjek } \\
\text { mengalami kekeliruan pada saat menggambarkan } \\
\text { garis tinggi } V W \text { dan } V X \text {, dimana tidak memuat } \\
\text { konsep garis tinggi dan subjek keliru dalam membuat } \\
\text { garis } W Y \text { karena garis } W Y \text { yang dibuat subjek tidak } \\
\text { sesuai dengan informasi yang diminta pada soal. } \\
\text { Subjek memulai dengan membuat sebuah } \\
\text { jajargenjang RSTV. Kemudian meletakkan titik W } \\
\text { kemudian menarik garis dari titik V ke titik W. } \\
\text { Selanjutnya X nya itu berada pada } T S \text { dan garis } W Y \\
\text { membagi dua diagonal } V S \text { sehingga titik Y berada } \\
\text { diantara } V T \text {. }\end{array}$ \\
\hline $\begin{array}{l}\text { Pada soal nomor la subjek menuliskan satu pasangan } \\
\text { segitiga yang kongruen dan menjelaskan dengan } \\
\text { memberikan bukti kekongruenan pasangan segitiga } \\
\text { yang ditemukan dengan sisi yang bersesuaian sama } \\
\text { panjang. }\end{array}$ & $\begin{array}{l}\text { Pada soal nomor 1a subjek menuliskan satu pasangan } \\
\text { segitiga yang kongruen dan menjelaskan dengan } \\
\text { memberikan bukti kekongruenan pasangan segitiga } \\
\text { yang ditemukan dengan postulat sisi-sudut-sisi. }\end{array}$ \\
\hline $\begin{array}{l}\text { Pada soal nomor } 2 \text { b subjek menuliskan dua pasangan } \\
\text { segitiga yang sebangun dan menjelaskan dengan } \\
\text { memberikan bukti kesebangunan segitiga tersebut } \\
\text { berdasarkan panjang sisi yang bersesuaian sama dan } \\
\text { sudutnya sama besar }\end{array}$ & $\begin{array}{l}\text { Pada soal nomor } 2 \mathrm{~b} \text { subjek menuliskan menuliskan } \\
\text { satu pasangan segitiga yang sebangun dengan melihat } \\
\text { bentuk segitiganya sama dan besar sudutnya sama. }\end{array}$ \\
\hline
\end{tabular}

Berdasarkan tabel 4, terlihat bahwa subjek pemahaman matematika rendah laki-laki (SLR) dan subjek pemahaman matematika rendah perempuan (SPR) dalam menyelesaikan masalah bangun datar segitiga cenderung terhadap kemampuan representasi visual. Pada soal membuat ilustrasi gambar dari wacana yang diberikan, subjek SLR merepresentasikan soal cerita kedalam bentuk gambar, dimana SLR menggambar berdasarkan informasi soal,

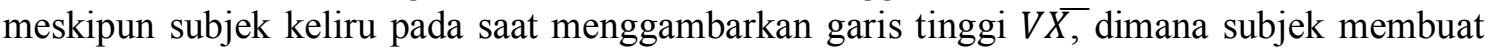
titik $\mathrm{X}$ pada perpanjangan garis $R \bar{S}$ dan menarik garis dari titik $\mathrm{V}$ ke titik $\mathrm{X}$ dengan memotong garis $T \bar{S}$. Sedangkan subjek SPR dalam merepresentasikan soal cerita kedalam bentuk gambar berdasarkan informasi soal, meskipun subjek mengalami kekeliruan pada saat menggambarkan garis tinggi $V W \bar{W}$ dan $V \bar{X}$, dimana tidak memuat konsep garis tinggi dan subjek keliru dalam membuat garis $W \bar{Y}$ karena garis $W Y \bar{Y}$ yang dibuat subjek tidak sesuai dengan informasi yang diminta pada soal.

Subjek SLR juga menemukan satu pasangan segitiga yang kongruen dan memberikan bukti kekongruenan pasangan segitiga yang ditemukan dengan sisi yang bersesuaian sama panjang, serta menemukan dua pasangan segitiga yang sebangun dan membuktikan kesebangunan segitiga tersebut berdasarkan panjang sisi yang bersesuaian sama dan sudutnya sama besar. Sedangkan subjek SPR menemukan satu pasangan segitiga yang kongruen dan memberikan bukti kekongruenan pasangan segitiga yang ditemukan dengan postulat sisi-sudutsisi, serta menemukan satu pasangan segitiga yang sebangun dengan melihat bentuk segitiganya sama dan besar sudutnya sama. Namun, segitiga kongruen dan sebangun yang disebutkan oleh subjek SLR dan SPR tidak menjelaskan konsep kekongruenan dan kesebangunan itu sendiri. Hal tersebut mengungkapkan bahwa subjek laki-laki dan perempuan tidak memahami konsep kesebangunan dan kekongruenan. Hal ini sejalan dengan penelitian dari Herdiman dkk (2018) bahwa siswa dengan skor rendah tidak mengerti konsep, tidak memahami perbedaan kesebangunan dan kekongruenan, dan tidak mengerti rumus yang harus digunakan, sehingga siswa dengan kemampuan representasi rendah hanya mengerjakan apa yang dia tahu. Sejalan 
dengan penelitian Aryanti \& Nursangaji (Herdiman dkk, 2013) yang menyatakan bahwa siswa dengan kemampuan representasi memiliki kesulitan yang berbeda-beda baik dari siswa skor tinggi, skor sedang dan skor rendah.

\section{Kesimpulan dan Saran \\ 1. Kesimpulan}

Berdasarkan pembahasan hasil penelitian, dapat ditarik beberapa kesimpulan tentang gambaran kemampuan representasi mahasiswa calon guru dalam menyelesaikan masalah geometri berdasarkan pemahaman matematika dan gender.

[1] Kemampuan representasi mahasiswa laki-laki calon guru dengan pemahaman matematika tinggi, sedang dan rendah dalam menyelesaikan masalah bangun datar segitiga cenderung menggunakan representasi visual.

[2] Kemampuan representasi mahasiswa perempuan calon guru dengan pemahaman matematika tinggi, sedang dan rendah dalam menyelesaikan masalah bangun datar

\section{Saran} segitiga cenderung menggunakan representasi visual.

Berdasarkan kesimpulan akhir penelitian ini, maka peneliti menyarankan beberapa hal yakni sebagai bahan perbaikan untuk penelitian sejenis selanjutnya, kiranya dapat diperhatikan beberapa hal berikut:

[1] Bagi mahasiswa calon guru diharapkan diharapkan lebih banyak mengerjakan latihan-latihan soal yang terkait dengan geometri terkhusus materi kekongruenan dan kesebangunan segitiga untuk melatih kemampuan representasinya.

[2] Bagi peneliti lain yang berminat pada penelitian seperti ini untuk mengkaji lebih spesifik pada salah satu indikator representasi matematika sehingga pembahasan yang diberikan mampu diuraikan lebih mendalam.

\section{DAFTAR PUSTAKA}

Ahmad, A., Tarmizi, R. A., \& Nawawi, M. (2010). Visual Representations in Mathematical Word Problem Solving among Form Four Students in Malacca. Procedia - Social and Behavioral Sciences, 8(5), 356-361.

Amaliyah, R., \& Mahmud, N. (2018). Analisis Kemampuan Representasi Matematis Dalam Pemecahan Masalah Geometri Serta Faktor-Faktor yang Mempengaruhinya. Jurnal Review Pembelajaran Matematika, 3(2), 146-160.

Cahdriyana, R. A., Sujadi, I., \& Riyadi. (2014). Representasi Matematis Siswa Kelas VII di SMP N 9 Yogyakarta dalam Membangun Konsep Sistem Persamaan Linear Dua Variabel. Jurnal Pembelajaran Matematika, 2(6), 632-642.

Faradiba, R., Susiswo, S., \& As'ari, A. R. (2019). Representasi Visual Dalam Menyelesaikan Masalah Pecahan. Jurnal Pendidikan: Teori, Penelitian, dan Pengembangan, 4(7), 885891.

Goldin, G. A. (2002). Representation in mathematical learning and problem solving. Handbook of international research in mathematics education, 197, 218. 
Herdiman, I., Jayanti, K., Pertiwi, K. A., \& Naila, R. (2018). Kemampuan Representasi Matematis Siswa SMP pada Materi Kekongruenan dan Kesebangunan. Jurnal Elemen, 4(2), 216-229.

Ilyas, M., \& Basir, F. (2016). Analysis Of Student's Conceptual Understanding Of Mathematics On Set At Class VII SMP Frater Palopo. Proceedings of ICMSTEA 2016: International Conference on Mathematics, Science, Technology, Education, and Their Applications, Makassar, Indonesia, 3rd-4th October 2016, 1(1), 96-102.

Imamuddin, M. (2018). Kemampuan Spasial Mahasiswa Laki-Laki Dan Perempuan Dalam Menyelesaikan Masalah Geometri. Humanisma: Journal of Gender Studies, 1(2), 38-47.

Marufi, Pasandaran, R. F., \& Yogi, A. (2018). Pemahaman Konsep Geometri Mahasiswa Berdasarkan Gaya Kognitif Mahasiswa. Proximal Jurnal Penelitian Matematika Dan Pendidikan Matematika, 1(2), 56-67.

Mulyati. (2016). Peningkatan Kemampuan Pemahaman dan Representasi Matematis Siswa SMA Melalui Strategi Preview-Question-Read-Reflect-Recite-Review. Jurnal Analisa, II(September), 36-55.

Özkan, A., Arikan, E. E., \& Özkan, E. M. (2018). A Study on the Visualization Skills of 6th Grade Students. Universal Journal of Educational Research, 6(2), 354-359.

Risnawati. (2012). Pengaruh Pembelajaran dengan Pendekatan Induktif-Deduktif Berbantuan Program Cabri Geometry terhadap Peningkatan Kemampuan Representasi Matematis Siswa Sekolah Menengah Pertama. Tesis SPs UPI. Bandung. Tidak Diterbitkan.

Ruswana, A. M. (2019). Analisis Kemampuan Pemahaman Matematis Mahasiswa Pada Mata Kuliah Aljabar Linier Elementer. Jurnal Pendidikan Matematika, 03(02), 293-299.

Sabirin, M. (2014). No Title. Jurnal Pendidikan Matematika UIN Antasari, 01(2), 33-44.

Santrock, J. W. (2004). Psikologi Pendidikan (Edisi Kedua). Jakarta: Kencana.

Stylianou, D. A. (2011). An Examination of Middle School Students' Representation Practices in Mathematical Problem Solving Through the Lens of Expert Work: Towards an Organizing Scheme. Educational Studies in Mathematics, 76(3), 265-280.

Suherman, E. (2001). Common Text Book Strategi Pembelajaran Matematika Kontemporer. Bandung: UPI-JICA.

Van Garderen, D., \& Montague, M. (2003). Visual-Spatial Representation, Mathematical Problem Solving, and Students of Varying Abilities. Learning Disabilities Research and Practice, 18(4), 246-254.

Utaminingsih, A. (2017). Gender dan Wanita Karir. Malang: UB Press. 